\title{
ABSTRAK \\ UJI EKSTRAK CABAI RAWIT SEBAGAI PESTISIDA NABATI UNTUK MENGENDALIKAN HAMA ULAT TITIK TUMBUH PADA TANAMAN SAWI
}

\author{
Nur Alim Natsir, Dosen Program Studi Pendidikan Biologi, \\ Fakultas Ilmu Tarbiyah dan Keguruan IAIN Ambon, \\ 085243549813, Email: nuralimnatsir@gmail.com
}

\begin{abstract}
Penelitian ini bertujuan untuk mengetahui pengaruh dari berbagai konsentrasi yang diujikan terhadap persentase mortalitas dan persentase intensitas kerusakan hama ulat titik tumbuh (Crocidolomia binotalis Zell.). Rancangan percobaan yang digunakan dalam penelitian ini adalah Rancangan Acak Lengkap (RAL) dengan lima perlakuan dan tiga ulangan. Perlakuan ini terdiri dari kontrol, tanpa ekstrak cabai rawit (C0), 20\% ekstrak cabai (C1), 40\% estrak cabai (C2), 60\% ekstrak cabai (C3), dan $80 \%$ ekstrak cabai (C4).Hasil penelitian menunjukan bahwa perlakuan konsentrasi C4 (80 \%) memberikan pengaruh yang sangat nyata dengan nilai persentase rata-rata tertinggi dibanding perlakuan yang lainnya.
\end{abstract}

Kata kunci: ekstrak cabe rawit, pestisida nabati, hama ulat

\section{ABSTRACT \\ CAYENNE EXTRACT TEST AS VEGETABLE PESTICIDES TO CONTROL PEST CATERPILLARS ON PLANTS GROWING POINT OF MUSTARD GREENS}

\begin{abstract}
This research aims to know the influence of different concentrations of the tested subjects of mortality and percentage percentage point pest damage intensity grows (Crocidolomia binotalis Zell.). The experimental design used in this study was a randomized Complete Design (RAL) with five treatments and three replicates. This treatment consists of control, without the extract of cayenne pepper (C0), 20\% extract of chilli (C1), $40 \%$ estrak chili (C2), $60 \%$ extract (C3), chili and chili extract $80 \%$ (C4). Results of the study showed that treatment of the $\mathrm{C} 4$ concentrations $(80 \%)$ gives a very real influence with the highest average percentage compared to other treatments
\end{abstract}

Keywords: extract, cayenne pepper, vegetable pesticides, pest 
Organisme pengganggu tanaman holtikultura adalah semua jenis organisme yang dapat menurunkan atau merusak hasil tanaman holtikultura. Organisme pengganggu tanaman ini umumnya dibedakan menjadi gulma, hama dan mikroorganisme patogenik yang menyebabkan penyakit tanaman. Hama pada prinsipnya adalah herbivora yang memangsa tanaman budidaya sehingga menyebabkan penurunan hasil atau mengurangi nilai estetika tanaman tersebut. Tidak semua herbivora tergolong hama, karena tidak semua herbivora memangsa tanaman budidaya. Hama kadangkala merupakan jenis serangga yang pada kondisi normal hanya menimbulkan kerusakan yang tidak serius pada tanaman budidaya, tetapi jika terjadi ledakan populasinya baru akan menyebabkan penurunan secara nyata. Ledakan populasi hama ini dapat terjadi karena keadaan iklim atau kesalahan pengelolaan oleh manusia.

Kendala yang sering dihadapi oleh petani adalah keberadaan hama yang menyerang tanaman holtikultura pada tanaman sawi yaitu ulat krop kubis (Crocidolomia binotalis Zell). Trizelia, menyatakan bahwa serangga ini dikenal juga sebagai hama yang sangat rakus dan larva terutama memakan daun-daun yang masih muda, tetapi juga dapat menyerang daun yang agak tua kemudian menuju kebagian titik tumbuh sehingga bagian titik tumbuh habis, akibatnya pembentukan krop akan terhambat atau berhenti. Kerusakan yang ditimbulkan akan menurunkan hasil sampai $100 \%$. Tanaman sawi dalam stadia pertumbuhan sangat rentan terhadap serangan hama, terutama hama perusak daun (Plutella xylostella, dan Crocidolomia binotalis) (Surachman E \& Suryanto AW, 2007). Petani sawi dalam mengendalikan hama Crocidolomia binotalis kebanyakan menggunakan insektisida yang beraneka ragam konsentrasi tinggi serta interval penyemprotan yang terlalu dekat sehingga dapat menimbulkan efek residu pestisida yang dapat mengurangi harga saing ekspor. Untung, mengemukakan bahwa dampak negatif yang ditimbulkan akibat penggunaan pestisida yang tidak bijaksana antara lain adalah terjadinya resistensi hama, resurgensi hama sasaran dan residu pestisida. Ameriana, mengatakan bahwa penggunaan insektisida secara terus menerus akan merusak lingkungan atau agroekosistem. Selain itu kandungan 
pestisida pada sayuran sangat tinggi sehingga sangat cukup membahayakan para konsumen, karena itu kesadaran masyarakat untuk mengkonsumsi sayuran yang bebas dari pestisida.

Crocidolonia binotalis termasuk salah satu hama utama tanaman sawi, kerusakan yang diakibatkan oleh hama ini terutama pada daun-daun yang masih mudah hingga ke titik tumbuh. Selain tanaman sawi dan selada, hama ini juga dapat menyerang tanaman kol, kol bunga, lobak dan lain-lain. Peraturan pemerintah No 6 tahun 1995 pasal 19 dalam Kasumbogo untung menyatakan bahwa pengguanaan pestisida sintetis dalam rangka pengendalian organisme pengganggu tanaman (OPT) merupakan alternatif terakhir dan dampak yang ditimbulkan harus di tekan seminimal mungkin. Indiyani dan Gothama Melanjutakan untuk mengatasi hal tersebut telah dianjurkan untuk menggunakan konsep pengendalian hama terpadu (PHT) dengan salah satu komponen adalah pengendalian hayati.

Salah satu alternatif yang dapat di lakukan untuk mengatasi masalah tersebut juga adalah dengan penggunaan pestisida nabati. Pengguanaan pestisida nabati selain dapat mengurangi pencemaran lingkungan, harganya relatif lebih murah apabila dibandingkan dengan pestisida sintetis/kimia. Berdasarkan studi dari berbagai pustaka, ada beberapa jenis tanaman yang dapat dimanfaatkan sebagai pestisida nabati melalui teknologi sederahana. Jenis-jenis tanaman tersebut beserta bagiannya antara lain ranting dan daun pacar cina, umbi gadung, akar batang dan daun tembakau, biji sirsak, buah cabai rawit, daun pepaya, dan lainlain.

Secara umum, cabai digunakan sebagai bumbu kecuali cabai paprika yang dapat pula digunakan sebagai salad atau lalap. Selain sebagai bumbu, buah cabai juga dapat dimanfaatkan sebagai pestisida nabati. Menurut Suyono dkk, buah cabai kecil (Capsicum frutescens) dapat digunakan untuk mengendalikan semut, apids dan Sitophilus oryzae dan anti virus. Hal ini di akibatkan karena adanya kandungan Capsicin dari cabai tersebut. Pada penelitian sebelumnya buah cabai rawit (Capsicum frutescens) telah digunakan untuk mengendalikan hama ulat titik tumbuh pada tanaman sawi akan tetapi belum di ketahui konsentrasi yang efektif untuk digunakan. 


\section{METODE PENELITIAN}

Penelitian ini menggunakan tipe eksperimen kuantitatif

dengan menggunakan Rancangan Acak Lengkap (RAL) untuk menghitung hasil penelitian. Penelitian ini dilakukan dengan 5 perlakuan dan 3 ulangan. Sehingga diperoleh 15 unit percobaan, setiap unit percobaan terdiri dari 10 hama ulat titik tumbuh. Variabel Bebas (X): Konsentrasi ekstrak cabai rawit merupakan variabel bebas yang dilihat pengaruhnya terhadap mortalitas Crocidolomia binotalis dan intensitas kerusakan daun tanaman sawi. Variabel Respon (Y): Mortalitas hama Crocidolomia binotalis dan intensitas kerusakan daun merupakan variabel respon yang diamati dan diukur untuk menentukan pengaruh yang disebabkan oleh penggunaan ekstrak buah cabai rawit.

Adapun langkah-langkah yang dilakukan dalam penelitian ini adalah sebagai berikut:

\section{Penyiapan tanaman}

Tanaman yang dipakai dalam penelitian ini adalah tanaman sawi (Brassica Junceae L.) yang berjumlah 30 tanaman. Caranya yaitu dengan mencari lahan-lahan terdekat yang terdapat tanaman tersebut, untuk infestasi serangga, tanaman yang dipilih harus tanaman yang sehat.

2. Penyediaan serangga

Serangga yang akan digunakan dicari dan dikumpulkan dari tanaman sawi yang telah terserang hama Crocidolomia binotalis. Hama yang digunakan adalah hama pada instar II.

3. Pembuatan larutan

Setelah serangga tersedia, bahanbahan yang telah disiapkan dibuat menjadi ekstrak.

a. Timbanglah buah cabai

b. Buah cabai yang telah ditimbang dicampurkan dengan air $200 \mathrm{ml}$ kemudian dihaluskan dengan menggunakan blender

c. Ekstrak kasar buah cabai (ekstrak stok) yang telah siap kemudian diukur sesuai ukuran dan dibuat menjadi larutan konsentrasi

d. Larutan konsentrasi yang telah siap kemudian dibiarkan \pm 12 jam

4. Infestasi serangga

Untuk pelepasan serangga ke tanaman dilakukan saat ekstrak sudah siap 5. Penyemprotan

Setelah serangga diinfestasikan, ekstrak yang telah siap digunakan langsung disemprotkan. Penyemprotan 
dilakukan dengan volume larutan ekstrak cabai $100 \mathrm{ml}$ tiap perlakuan yang disemprotkan pada tanaman antara $0,1 \mathrm{ml}-$ $0,2 \mathrm{ml} /$ tanaman.

6. Pengamatan dilakukan selama kurang lebih tiga hari dengan cara mengamati :

a. Mortalitas serangga

b. Intensitas kerusakan daun setelah aplikasi

7. Pengambilan data
Kematian hama Crocidolomia binotalis dicatat setelah \pm 5 jam, juga dihitung intensitas kerusakan yang di akibatkan oleh hama tersebut \pm 24 jam setelah aplikasi dilakukan. Data yang diperoleh kemudian direkap dan ditentukan konsentrasi pestisida dari ekstrak cabai rawit yang paling banyak menyebabkan kematian dan intensitas kerusakan yang ditimbulkan.

Prosedur pembuatan Ekstrak

Tabel 1 Perlakuan Konsentrasi Ekstrak Cabai Rawit Adalah Sebagai Berikut :

\begin{tabular}{|c|c|c|c|}
\hline Perlakuan & $\begin{array}{c}\text { Ekstrak kasar buah cabai } \\
\text { (gram) }\end{array}$ & $\begin{array}{c}\text { Volume akhir larutan } \\
(\mathrm{ml})\end{array}$ & $\begin{array}{c}\text { Detergen yang } \\
\text { ditambahkan } \\
\text { (gram) }\end{array}$ \\
\hline C0 & 0 gram & $100 \mathrm{ml}$ & 0 grm \\
C1 & 20 gram & $100 \mathrm{ml}$ & $5 \mathrm{grm}$ \\
C2 & 40 gram & $100 \mathrm{ml}$ & $5 \mathrm{grm}$ \\
C3 & 60 gram & $100 \mathrm{ml}$ & $5 \mathrm{grm}$ \\
$\mathrm{C} 4$ & 80 gram & $100 \mathrm{ml}$ & $5 \mathrm{grm}$ \\
\hline
\end{tabular}

Adapun langkah pembuatan jumlah ekstrak yang dibutuhkan pada tiaplarutan konsentrasi pestisida nabati dari tiap perlakuan (jumlah ekstrak dapat cabai rawit adalah sebagai berikut:

dilihat dalam tabel)

1. Perlakuan I (C1)

Dari ekstrak kasar buah cabi rawit (ekstrak stok) $100 \%$, diambil 20 gram kemudian ditambahkan aquades sampai mencapai volume $100 \mathrm{ml}$. setelah itu tambahkan dengan 5 gram detergen dan dicampur hingga merata. Larutan tersebut kemudian dibiarkan \pm 12 jam

2. Larutan siap diaplikasi

Pada perlakuan

$\mathrm{C} 2, \mathrm{C} 3, \mathrm{C} 4$ caranya sama dengan langkah pada perlakuan I (C1) tetapi berbeda dalam

\section{Analisis Data}

Teknik analisis data disini ditujukan untuk melihat pengaruhpengaruh utama dan interaksi faktor percobaan dengan derajat ketelitian dan kepentingan yang setara.

Semua data yang diperoleh dari percobaan harus dianalisis sesuai dengan yang direncanakan semula hasil-hasilnya diinterpretasikan selaras dengan kondisikonsdisi percobaan, hipotesis yang diuji, dan atas dasar hubungan hasil-hasil ini 
dengan fakta-fakta yang telah terbukti benar menurut hasil-hasil penelitian. Dalam menganalisis hasil yang diperoleh dari penelitian maka rancangan yang digunakan adalah Rancangan Acak Lengkap (RAL). RAL merupakan rancangan yang paling sederhana jika dibandingkan dengan rancanganrancangan lainnya. Dalam rancangan ini tidak terdapat lokal kontrol, sehingga sumber keragaman yang diamati hanya perlakuan dan galat saja. Oleh karena itu RAL umumnya cocok digunakan kondisi lingkungan, alat, bahan dan medianya homogen. Kondisi ini hanya dicapai di ruang-ruang terkontrol seperti di laboraturium dan di rumah kaca (green house). Data yang terkumpul dari hasil pengukuran dianalisis dengan menggunakan uji analisis varian pada taraf signifikan 5\% jika ada pengaruh maka dianjurkan dengan uji BNT.

\section{HASIL PENELITIAN}

Berdasarkan hasil penelitian setelah diuji secara statistik diperoleh bahwa konsentrasi ekstrak cabai rawit memberikan pengaruh yang sangat nyata pada persentase mortalitas hama ulat titik tumbuh dan tidak berpengaruh nyata pada persentase intensitas kerusakan.

Hasil pengamatan persentase mortalitas hama ulat titik tumbuh (Crocidolomia binotalis Zell.) dan intensitas kerusakan daun tanaman sawi pada berbagai konsentrasi ekstrak cabai rawit adalah sebagai berikut:

\section{Mortalitas Hama Ulat Titik Tumbuh (Crocidolomia binotalis Zell.)}

Persentase mortalitas hama ulat titik tumbuh serta sidik ragamnya disajikan pada Tabel Lampiran 1a dan 1b. Sidik ragam menunjukkan bahwa konsentrasi ekstrak cabai rawit memberikan pengaruh yang sangat nyata terhadap persentase mortalitas hama ulat titik tumbuh pada tanaman sawi.

Tabel 2. Hasil Uji Beda Nyata rata-rata Persentase Mortalitas Hama Ulat Titik Tumbuh (Crocidolomia binotalis Zell.) Pada Berbagai Konsentrasi Ekstrak Cabai Rawit.

\begin{tabular}{|l|l|}
\hline Konsentrasi & Rata-rata Persentase Mortalitas \\
Ekstrak Cabai Rawit (\%) & $0^{\mathrm{a}}$ \\
\hline 0 & $16,6^{\mathrm{b}}$ \\
20 & $26,6^{\mathrm{b}}$ \\
40 & $60^{\mathrm{c}}$ \\
60 & $83,3^{\mathrm{d}}$ \\
\hline BNT $_{0,05}=9,78$ \\
\hline
\end{tabular}

Keterangan : Angka-angka yang diikuti oleh huruf yang sama berarti tidak berbeda nyata pada taraf uji BNT $\alpha=0,05$. 
Tabel di atas menunjukan bahwa konsentrasi ekstrak cabai rawit 80\% (C4) menghasilkan persentase rata-rata moratlitas tertinggi $(83,3 \%)$ dan berbeda dengan perlakuan lainnya $(\mathrm{C} 0, \mathrm{C} 1, \mathrm{C} 2$, C3) yang menghasilkan persentase ratarata mortalitas masing-masing 60\%, 26,6\%, 16,6\%, dan 0\%. Konsentrasi ekstrak cabai rawit $60 \%$ (C3) menghasilkan persentase rata-rata mortalitas $(60 \%)$ dan berbeda pula dengan perlakuan lain $(\mathrm{C} 0, \mathrm{C} 1, \mathrm{C} 2, \mathrm{C} 4)$, sedangkan pada konsentrasi 40\% (C2) menghasilkan persentase rata-rata mortalitas $(26,6 \%)$ dan berbeda dengan perlakuan-perlakuan lain $(\mathrm{C} 0, \mathrm{C} 3, \mathrm{C} 4)$ tetapi tidak berbeda dengan konsentrasi $20 \%$ (C1) dimana persentase rata-rata mortalitas yang dihasilkan adalah $(16,6 \%)$. Persentase rata-rata mortalitas terendah terdapat pada perlakuan tanpa pemberian ekstrak cabai rawit $(\mathrm{C} 0)$.

\section{Intensitas Kerusakan}

Persentase intensitas kerusakan daun tanaman sawi serta sidik ragamnya disajikan pada Tabel Lampiran 2a dan 2b. Sidik ragam menunjukan bahwa konsentrasi ekstrak cabai rawit memberikan pengaruh yang tidak nyata terhadap persentase intensitas kerusakan daun tanaman sawi.

Tabel 3. Data Persentase Rata-rata Intensitas Kerusakan Daun Tanaman Sawi

Pada Berbagai Konsentrasi Ekstrak Cabai Rawit.

\begin{tabular}{|l|l|}
\hline $\begin{array}{l}\text { Konsentrasi } \\
\text { Ekstrak Cabai Rawit (\%) }\end{array}$ & $\begin{array}{l}\text { Rata-rata Persentase Intensitas Kerusakan Daun } \\
\text { Sawi }\end{array}$ \\
\hline 0 & $19,44^{\mathrm{a}}$ \\
20 & $3,7^{\mathrm{a}}$ \\
40 & $1,85^{\mathrm{a}}$ \\
60 & $1,85^{\mathrm{a}}$ \\
80 & $2,77^{\mathrm{a}}$ \\
& \\
\hline BNT $_{0,05}=16,8$ & \\
\hline
\end{tabular}

Keterangan : Angka-angka yang diikuti oleh huruf yang sama berarti tidak berbeda nyata pada taraf uji BNT $\alpha=0,05$.

\section{PEMBAHASAN}

\section{Mortalitas Hama Ulat Titik Tumbuh.}

Mortalitas adalah ukuran jumlah kematian (umumnya, karena akibat yang spesifik) pada suatu populasi. Penyebab kematian suatu individu umumnya disebabkan oleh beberapa faktor diantaranya faktor lingkungan hidup (habitat). Hasil analisis statistik 
memperlihatkan bahwa pengaruh yang sangat nyata terhadap mortalitas terdapat pada konsentrasi $80 \%$, konsentrasi ini merupakan konsentarsi yang mengasilkan rata-rata persentase mortalitas tertinggi dibanding dengan konsentrasi-konsentrasi lain $(60 \%, 40 \%, 20 \%$, dan $0 \%)$. Hal ini diakibatkan karena kandungan capsicin pada konsentarsi $80 \%$ lebih tinggi dari pada kandungan capsicin pada konsentrasi $60 \%, 40 \%, 20 \%$, dan $0 \%$.

Capsicin yaitu zat kimia yang menimbulkan rasa pedas yang ada dalam tumbuh-tumbuhan seperti cabai. Rasa pedas ini muncul karena capsicin menciptakan isyarat yang sama bagi otak seperti saat kulit terkena panas. Capsicin merupakan kapsaisinoid yang utama didalam cabai yang diikuti oleh dihidrokapsaisin. Capsicin dengan rumus kimia $\mathrm{C}_{18} \mathrm{H}_{27} \mathrm{O}_{3} \mathrm{~N}$ memiliki banyak manfaat selain dikenal sebagai salah satu bahan penyedap makanan yaitu sebagai bahan dasar pestisida nabati. Hal ini dikarenakan kandungan capsicin (rasa pedas) dan kandungan capsicol (rasa panas) dari buah cabai tersebut sehingga apabila terkontaminasi dengan kulit atau bagian tubuh akan terasa pedas atau panas.
Menurut Suyono dkk (1999), buah cabai rawit (Capsicum frutescens) dapat digunakan untuk mengendalikan semut, apids dan Sitophilus oryzae dan anti virus. Hal ini diakibatkan karena adanya kandungan Capsicin dari cabai tersebut. Pracaya (2010) mengemukakan bahwa buah cabai rawit (Capsicum frutescens L.) juga dapat digunakan untuk membasmi ulat tritip (Plutella xylostella L.). Dari hasil persentase mortalitas tertinggi yang diperlihatkan oleh perlakuan $\mathrm{C} 4(80 \%)$ menunjukan bahwa dosis pada perlakuan yang digunakan sudah tepat. Hal ini dapat dlihat dari persentase mortalitas yang diperlihatakan dari perlakuan pada konsentarasi tersebut. Menurut Djojosumarto, mengemukakan bahwa organisme pengganggu tumbuhan (OPT) hanya dapat dikendalikan bila terpapar (terekpose) oleh bahan aktif pestisida dalam jumlah yang cukup untuk mengendalikan atau mematikannya. Misalnya, larva Spodoptera litura instar 1 akan mati bila terpapar oleh 1,7 nanogram Monokrotofos, larva instar 2 baru mati bila terpapar 5 ng Monokrotofos, dan sebagainya. Dalam toksologi, kuantitas bahan aktif racun yang diberikan jasad sasaran disebut takaran atau dosis (dose). 
Terdapat hubungan langsung antara bahan aktif racun terhadap proses-proses yang berlangsung dalam proses biologi organisme, termasuk OPT. Bahan racun hanya akan meracuni organisme (termasuk OPT) pada takaran tertentu.

\section{Intensitas Kerusakan}

Serangan merupakan bentuk aktifitas Organisme Pengganggu Tanaman (OPT) untuk menimbulkan kerusakan pada tanaman, sedangkan kerusakan adalah efek dari aktifitas OPT pada tanaman dan biasanya ditinjau dari segi fisiologi dan ekonomis. Kerusakan tanaman karena serangan OPT sangat beragam tergantung pada gejala serangannya, sehingga dikenal kerusakan mutlak dan tidak mutlak. Kerusakan mutlak adalah kerusakan yang terjadi secara permanen/keseluruhan pada tanaman dan bagian tanaman yang akan dipanen, misalnya kematian seluruh jaringan tanaman dan layu, sedangkan yang dianggap mutlak seperti terjadinya busuk, rusaknya sebagian jaringan tanaman sehingga tanaman atau bagian tanaman tidak produktif lagi. Kerusakan tidak mutlak, kerusakan sebagian tanaman seperti daun, bunga, buah, ranting, cabang, dan batang.
Berdasarkan hasil analisis ragam terhadap intensitas kerusakan hama ulat titik tumbuh menunjukan bahwa perlakuan tidak berpengaruh nyata terhadap intensitas kerusakan. Hal ini dapat diakibatkan karena teknik aplikasi pestisida yang kurang baik seperti penggunaan dosis yang tidak tepat, waktu penyemprotan, tidak tepat sasaran, serta tidak tepat cara, sehingga hasilnya tidak terlihat. Maspary 2010 mengemukakan dalam penggunaan pestisida, pengguanaan dosis dibawah anjuran dapat mengakibatkan hama/ penyakit tidak mati serta mengakibatkan hama menjadi resisten. Waktu penyemprotan yang baik sebaiknya dilakukan pagi hari sebelum jam 10 dan sore hari setelah jam 3, karena dipagi hari dipastikan belum banyak angin dan matahari belum terik dan disaat pagi hama masih enggan bergerak. Kemudian cara yang tepat dalam aplikasi pestisida yaitu harus disesuaikan dengna bentuk atau formulasi pestisida tersebut. Dalam aplikasi pestisida harus disesuaikan dengan hama/penyakit sasaran, yaitu dengan mengetahui bagaimana cara hidupnya, apa kelemahan hama /penyakit tersebut dan cara kerja pestisida tersebut (kontak atau sistemik). Sejalan dengan 
pendapat yang dikemukakan oleh Djojosumarto. P bahwa faktor-faktor yang mempengaruhi keberhasilan pengendalian OPT adalah hubungan antara jenis pestisida yang digunakan dengan OPT karena tidak ada satu jenis pestisida untuk semua jenis OPT serta teknik aplikasi yang meliputi kepekaan sasaran dan waktu aplikasi.

$$
\text { Dalam melakukan aplikasi }
$$
keberhasilan pengendalian dapat dievaluasi dengan dua cara yaitu evaluasi biologis dan evaluasi fisik. Evaluasi dikatakan berhasil bila sesudah aplikasi populasi OPT menurun, serangan OPT terhenti (tidak meluas) atau tanaman tidak diserangan OPT sama sekali dibandingkan dengan tanaman yang tidak diaplikasi, sedangkan evaluasi fisik yaitu untuk menilai tingkat keberhasilan penyemprotan yang telah dilakukan misalnya evaluasi parameter penyemprotan seperti penutupan (coverage), ukuran droplet, dan volume aplikasi.

\section{KESIMPULAN}

Berdasarkan hasil penelitian yang diperoleh, maka dapat disimpulkan bahwa Konsentrasi ekstrak cabai rawit $80 \%$ menyebabkan mortalitas hama ulat titik tumbuh (Crocidolomia binotalis Zell.) tertinggi. Sedangkan untuk intensitas kerusakan, ekstrak cabai rawit tidak memperlihatkan pengaruh yang signifikan.

\section{SARAN}

1. Perlakuan ekstrak cabai rawit dengan konsentrasi $80 \%$ dapat dimanfaatkan untuk mengendalikan hama ulat titik tumbuh pada tanaman sawi.

2. Dalam melakukan aplikasi pestisida nabati perlu diperhatikan teknik aplikasi pestisida dan hubungan antara pestisisda yang digunakan dengan OPT serta waktu aplikasi agar pengendalian dapat dilihat hasilnya.

\section{DAFTAR PUSTAKA}

Amin Husna. 2007. Bercocok Tanam Cabai Rawit, cabai Merah, dan Cabai Jawa. CV Sinar Cemerlang Abad. Jakarta.

Djojosumarto Panut. 2008. Teknik Aplikasi Pestisida pertanian. PT Swadaya. Yogyakarta.

Http://www.Artikelteknik.Com/ArtikelTeknik-Pengamatan-Opt2011124524.Html, diakses tanggal 12 april 2012.

Http://Id.Wikipedia.Org/Wiki/Kapsaisin, diakses tanggal 15 Mei 2012

Jonathan Sarwono. 2006. Metode Penelitian Kuantitatif dan Kualitatif. PT Graha Ilmu. Yogyakarta. 
K. Hanafiah Ali. 2010. Rancangan

Percobaan Teori dan Aplikasi.

Rajawali Pers. Jakarta.

Maspary,

Http://www.Gerbangpertanian.Co

m/2010/04/Cara-Aplikasi-

Pestisida-Secara-Benar.Html, diakses tanggal 12 Mei 2012

Natawigena. 1992. Pestisida dan Penggunaanya. Jurusan Proteksi Tanaman. Fakultas Universitas Padjajaran. Bandung

Pitojo Setijo. 2003. Benih Cabai. PT Kanisius. Yogyakarta.

Pracaya. 2010. Hama dan Penyakit Tanaman. PT Penebar swadaya Jakarta.

Romadhon

Musa,

Http://Www.Scribd.Com/Doc/300 28425/Mia-Binotalis-Vs-

Nomuraea. diakses tanggal 18 Agustus 2011.

Scribd Ulat Titik Tumbuh. http://www.seribd.com/doc/27014 108/ulat-titik-tumbuh. diakses tanggal 18 Agustus 2011.

Sudarmo Subiyakto. 2005. Pestisida Nabati Pembuatan dan Pemanfaatannya. PT Kanisius. Yogyakarta.

Surachman E. dan Suryanto A.W. 2007. Hama Tanaman Masalah dan Solusinya. Kanisius Cetakan V. Yogyakarta.

Tim Penulis PS. 1992. Hama Penyakit Sayur dan Palawija. Penebar Swadaya. Jakarta.

Wawan Junaidi, Http://Wawan Junaidi.blogspot.com/2009/08/Def enisi Mortalitas.Html, diakses tanggal 12 April 2012.

Yatim W. 2007. Kamus Biologi. Yayasan Obor Indonesia. Jakarta. 